"This is an Accepted Manuscript of an article published by Taylor \& Francis Group in International Journal of Listening on 2/05/2012

available online:

http://www.tandfonline.com/10.1080/10904018.2001.10499044"

\title{
Listening and Referring to Voices: Students' Repertory in Educational Settings
}

\author{
Kent Adelmann, B.A. and doctoral student \\ Malmoe University, Sweden
}

When we construct our knowledge in educational settings we usually listen to many different voices, mediated through teachers, classmates, books, films, and so on. Eight students in teacher training were videotaped for 12 hours of group talks with a tutor over a six-month period. The overall purpose of the study was to describe the polyphonic nature of the discursive field of education and the interplay between various contexts and contextual resources in that social interaction.

The concept of intertextuality is adopted as a method to identify the polyphony of different voices. The explicit reported long-term listening is called the student's voice response, showing the repertory of contextual resources in use. Results from the study indicate that some of the students have a broad and some a narrow listening repertory when it comes to reported listening. The implications of these findings are discussed.

In Voices of the Mind (1997) Wertsch is concerned with the discipline of psychology and makes the following proposals against disciplinary fragmentation and isolation:

We need to develop the type of theoretical frameworks that can be understood and extended by researchers from a range of what now exist as separate disciplinary perspectives. Furthermore, and perhaps even more important, we need to formulate methodologies that do not automatically exclude the participation of researchers from a variety of disciplines (p. 4). 
'Listening' is at its very heart an interdisciplinary field and therefore it seems of particular importance to study the research issues within a broad framework which makes it possible for different disciplines to integrate in a general picture of the whole. I will argue that the theories of Bakhtin create such a theoretical framework across disciplinary boundaries, and I will adopt the concept of 'intertextuality' as a method of identifying different voices in educational settings. With Bakhtin's wordings the research question in this study is as follows: What kind of intertextual voices do the students use when they construct knowledge by using utterances from different contexts in dialogue with a current context? I will try to delimit my object of inquiry and, as Wertsch (1997) puts it, "create an object that does not put the investigator in the impossible position of having to provide a comprehensive analysis of everything before being able to take the first step" (p. 122). In doing so I will start the introduction with a comment on five of the fundamental concepts, before I show the concepts in work and conclude by demonstrating the analytical tools.

\section{INTRODUCTION}

\section{Intertextuality}

'Intertextuality', which literally means "between texts", is originally from literary theory implying that every literary work is consciously or unconsciously a part of a dialogue with other texts. The Waste Land (1922) by T.S. Eliot is often mentioned as an example of quotation and allusion technique where the writer is conscious of the dependence on and reference to literary history. However the concept of 'intertextuality' was not created until 1966 by Julia Kristeva $^{1}$ in an article about the Soviet language philosopher and literature researcher Mikhail Mikhailovich Bakhtin (1895-1975). ${ }^{2}$ Bakhtin argues that all utterances are dialogical and that both oral and literary language is characterized by polyphony where you can hear many voices (1984 [1929/1963], 1999 [1986]). This theoretical approach has been an inspiration in this work as a model for the analysis of strong and explicit intertextual relations in the students' dialogue during interaction.

Furthermore, Fairclough's Discourse and Social Change (1996) makes the concept of intertextuality more concrete by analyzing texts with different kinds of intertextuality and different modes of intertextual relations. Fairclough (1996) distinguishes between 'manifest intertextuality' and 'interdiscursivity/constitutive intertextuality', the former being "the explicit presence of other texts in a text" and the latter "the constitution of a text from a configuration of text types or discourse conventions" (p. 10). Within both kinds of intertextuality he claims there are three different modes of intertextual relations, namely sequential, embedded and mixed intertextuality. 'Sequential 
intertextuality" means that "different texts or discourse types alternate within a text", whereas 'embedded intertextuality' means that "one text or discourse type is clearly contained within the matrix of another" and 'mixed intertextuality" means that "texts or discourse types are merged in a more complex and less easily separable way" (s. 118).

Here we will only be concerned with manifest and sequential intertextuality. So, the specific purpose of the study is to suggest an alternative methodological approach in listening research (Wolvin et al., 1999) with listening as an intertextual phenomenon of listening and referring to voices.

Voice

In his famous book about Dostoevsky (1984 [1929/1963]) Bakhtin analyses the interplay between different voices in the polyphonic novel and makes the following definition of voice:

This includes height, range, timbre, aesthetic category (lyric, dramatic, etc.). It also includes a person's worldview and fate. A person enters into dialogue as an integral voice. He participates in it not only with his thoughts, but with his fate and with his entire individuality" (p. 293). ${ }^{3}$

Hence, a voice is not just words and sounds but "includes a person's worldview". Different voices mean different positions on the battlefield of everyday interaction ${ }^{4}$ and, as Baxter \& Montgomery (1996) have pointed out in their book on relationships, "Bakhtin's image of the 'voice' underscores communication as concrete, lived experience" (p. 234). So, when a voice creates utterances, those utterances are always an expression of a personal point of view or position.

\section{Utterance}

In Bakhtin's language theory about language as communication, a sentence is a unit of language, while an utterance is a unit of speech communication (1999 [1986]). According to Bakhtin the utterance has three basic features: boundaries, finalization and generic form. First, the boundaries of the utterance are determined by the change of speaker, that is when the listener becomes the speaker, because every utterance always has both an author and an addressee. This means that an utterance can vary in length from a single word to a novel.

Secondly, the finalization of the utterance implies that it is possible for the listener or reader to respond. When the listener understands the meaning "he simultaneously takes an active, responsive attitude toward it. He either agrees or disagrees with it (completely or partially), augments it, applies it, prepares for its execution, and so on" (1999 [1986], p. 68). Thirdly, the generic forms or conventions by which utterances are organized are called speech genres. "To 
learn to speak means to learn to construct utterances" and to use speech genres (1999 [1986], p. 78).

"Any utterance is a link in a very complexly organized chain of other utterances" in the speech communication, Bakhtin says (1999 [1986], p. 69). Among the links in the chain in the past, some are more distant from the immediate utterance and some comprise the immediately prior utterances, while the links in the future include the responses of both the "addressee"/listener in the immediate situation and the "superaddressee" beyond the immediate situation. ${ }^{5}$ So, any utterance echoes the past, one way or another, contributes with something new in the present situation, and anticipates a response in the future.

As Bentley (1997) has pointed out there is a time factor in the assessment of listening effectiveness. She presents the following four points of time as possible for assessment: pre-listening (listening environment, asking questions, preparing to listen), during listening (verbal and nonverbal feedback), postlistening - immediate (verbal and nonverbal response) and post-listening - longterm (verbal and nonverbal response at a later date). Among the examples of long-term listening she mentions "[g]iving an appropriate verbal response at a later date, such as a reference in a later conversation to what was said in the prior conversation" (Bentley, 1997, p. 55, italics by author). This study focuses on long-term listening, when an earlier utterance comes into dialogue with a new utterance in the present situation.

\section{Dialogue}

Holquist (1983) has declared that Bakhtin's "work may be summed up as dialogism" (p. 308). ${ }^{6}$ Dialogism is not a word Bakhtin used himself but within an European epistemology it means that language (speech) and knowledge emerge and develop through social interaction and communication (Dysthe, 1999). One could also say that dialogism is one variant within a dialectical approach, and Baxter \& Montgomery (1996) describe a perspective on Bakhtin's dialogism that emphasizes "a social self instead of a sovereign self, multivocal oppositions instead of binary contradictions, and indeterminate change instead of transcendent synthesis" (p. xiv). ${ }^{7}$

In Author and Hero (2000 [1979]) Bakhtin analyses the relationship between 'I' and 'the other' from a literary point of view. But this is also a philosophical work from the early twenties (1919-1924), with an ambiguity about whether he is talking about the writer or the speaker and a constant moving between the author of the novel and the speech situation. ${ }^{8}$ This is why Holquist (1983) makes the following analogous conclusion: "a speaker is to his utterance what an author is to his text" (p. 315). Just like an author is the creator of texts, every speaker is the creator of utterances and thus the creator of the self-other relationship through dialogue. 
Bakhtin extends the concept of dialogue to cover all verbal communication, oral and written dialogue as well as external and internal dialogue. Perhaps Bakhtin's dialogism, doublevoicedness and multivoicedness is most developed in Problems of Dostoevsky's Poetics (1984 [1929/1963), where his view on dialogic relationships finally comprises everything in human life:

The single adequate form for verbally expressing authentic human life is the open-ended dialogue. Life by its very nature is dialogic. To live means to participate in dialogue: to ask questions, to heed, to respond, to agree, and so forth (p. 293).

To Bakhtin, like a number of his contemporaries (Mead, 1976 [1934]; Vygotsky, 2000 [1934/1962]), cognition was not psychological in its origin, but social. The self is social and exists only in relation to others, thus the self is constructed through the dialogues between self and others. Bakhtin and his associates ${ }^{9}$ believed that language must always be studied in use and hence as a social phenomenon in a social environment. All language production is mainly dialogical and therefore the social interaction leaves traces in speech:

The life of the word is contained in its transfer from one mouth to another, from one context to another context, from one social collective to another, from one generation to another generation. In this process the word does not forget its own path and cannot completely free itself from the power of these concrete contexts into which it has entered (Bakhtin, 1984 [1929/1963], p. 202).

\section{Context}

Valentin Nikolaevich Volosinov (1895-1936) was another Soviet researcher who belonged to the Bakhtin Circle. In 1929 he published Marxism and the Philosophy of Language, ${ }^{10}$ in which the third part describes various forms of reported speech. ${ }^{11}$ He defined reported speech in the following way:

speech within speech, utterance within utterance and, at the same time, as speech about speech and utterance about utterance (Volosinov, 1996 [1929/1973], p. 115).

Moreover, Volosinov, focusing on the importance of context ${ }^{12}$ and the interplay between contexts, argues that "the true object of inquiry ought to be precisely the dynamic interrelationship of these two factors, the speech being reported (the other person's speech) and the speech doing the reporting (the author's speech)" (Volosinov, 1996 [1929/1973], p. 119). Thus, the context is an integral part of the utterance.

To Volosinov "[t]he meaning of a word is determined entirely by its context" (Volosinov, 1996 [1929/1973], p. 79), and to Stephen C. Pepper, contextualism is one out of four "relatively adequate" world views (Owen, 1997). ${ }^{13}$ This leads to a contextual approach to language, but from a pragmatic 
point of view contextualism has primarily a practical purpose (Owen, 1997). In this study the practical purpose of contextual analysis is to determine exactly what contextual resources the students are activating during interaction.

The concepts in work

In the following excerpt from a student conversation in teacher training, the speaker, Siv ${ }^{14}$ refers to an utterance by a non present previous speaker:

(1.) [Group guidance (GG) 2:71]

Siv: -Carolin also said that yesterday, really, that she, she didn't know the difference. Well, she didn't know if they were dyslectic or if they just hadn't learned how to read. [-Det sa ju Carolin igår också, egentligen, att hon, hon visste inte skillnaden. Ja, hon visste ju inte om de var dyslektiker eller om de bara inte hade lärt sig läsa.]

When the students are discussing the task of teaching the pupils how to read, Siv makes a reference to one of the lecturers the day before and can assume that everybody in the student group knows which Carolin she is referring to (key word underlined, the rough translation from Swedish by author with original excerpt between square brackets). In doing so she is stressing the difference between a medical and pedagogical point of view, and making a strong argument for looking at the pupils' problems with reading as a question of development.

As professional educators, we usually support our own position, increase the credibility in our arguments and make it easier to scrutinize our statements by referring to different texts and writers. Students in teacher training also use various kinds of reported speech, references and allusions when they are solving educational problems. This part of the study focuses on the sources the students are referring to when they interact in small groups.

In the following examples the students are referring to both Specialist Literature and their experience of the practical knowledge of education:

(2) [GG3:66]

Hanna: -That was also included in the book, that you should listen to the children and start from them and get to know them and show them respect. [-Det tog ju den boken upp också, att man ska lyssna på barnen och utgå ifrån dom och lära känna dom och visa respekt för dom.]

(3) [GG4:64]

Yvette: -I was so very, when I came out on my practice I just said "But God, these small children. I have no idea what I'm doing. I won't make it”. I was tremendously worried. 
[-Jag var ju väldigt, när jag kom ut på praktiken sa jag bara "Men Gud, de här små barnen. Jag har ingen aning om vad jag gör. Jag fixar inte det här”. Jag var jätteorolig.]

The last two examples are somewhat different from the first one. While the first example shows a teacher who was lecturing and is a case of traditional listening, the second shows a book that was read and the third the student's own experience from practice. But is this listening?

Going through the existing definitions of listening in the literature, Glenn (1989) examines fifty different descriptions of listening from 1925 to 1988. Her content analysis results in the following seven common key words: perception, attention, interpretation, remembering, response, spoken sounds and visual cues, with the latter two receiving the lowest frequency.

In 1996 the International Listening Association (ILA) adopted an official definition of listening:

Listening: the process of receiving, constructing meaning from, and responding to spoken and/or nonverbal messages (Purdy \& Borisoff, 1997, p. 6).

This definition was also accepted by the National Communication Association (NCA) as the listening standard in their K-12 standards and competencies document (National Communication Association, 1998, p. 1).

Glenn's study demonstrates many different perspectives on listening and indicates that each definition is dependent upon its use. This implies listening in all the preceding examples, including the seven concepts above. However, listening in this study is not limited to spoken sounds and visual cues or nonverbal messages but, following Bakhtin (1984 [1929/1963], 1999 [1986]), it also comprises written texts and communication with ourselves. In all three previous examples the students are listening and referring to voices: voices that are mediated through a speaker (1) or a writer (2) or a self (3); voices that are coming from within (3) or without $(1 \& 2)$. This also implies the importance of the listener's relation to different voices in different contexts.

In this study there is no difference made between real-time listening and experiences created afterwards. That is to say, there is no difference between listening to a voice and reflections on that experience. In both cases the reference is to an experience; for instance a reference to what a teacher said in practice (interpersonal) and what the student thought or felt about it afterwards (intrapersonal). Using the notion of 'listening' in this metaphorical way, you could say that the students are listening and referring to their experiences.

Since a teacher or an observer is never able to grasp the listener's listening itself, which is mostly internal, we have to be satisfied with the more or less arranged experience of real-time listening. No matter how you define listening and the listening process, what happens inside the student's head is a covert process for the teacher in the classroom, but the response from the students is available for research and can be used as an indication of earlier listening having 
taken place. While an interview or a self-report questionnaire lets you know what the student reports about his or her listening, research in real-time listening contexts makes it possible to assess what voices they have been listening to and how their reported listening contributes to the talk in the present interaction.

From a pedagogical point of view the question in this study is not the difference between thinking and listening, or between listening and reading, or between hearing, seeing and feeling. Nor is the question what medium the students are using when they are listening to utterances and making them part of their creation of meaning. On the operational level in the classroom the question is: What voices have the students been listening to? What sources do the students use and refer to when they are discussing educational problems? To answer this kind of question we have to work with an extended notion of listening in educational settings, and I will call this listening: Listening to voices (see Bakhtin, 1984 [1929/1963]).

\section{Analytical tools}

From Volosinov's definition of reported speech (above) it follows that when an utterance is taken away from its original context and is placed in a new utterance in another context, then we have an interplay between two different contexts within the same syntactical structure. The new utterance includes the old utterance in the form of a quotation (repetition), a paraphrase (transformation) or a combination of both. Thus, during the interaction the students are not merely in dialogue with each other, but also with different contexts. This also means that their reported listening can be seen as a dialogical response, and I will call that response the student's voice response.

As mentioned above, Bakhtin says that both oral and literary language are dialogical, and in the video texts the students give examples of intertextual references both to oral texts, e.g. lessons and lectures, and to written texts, e.g. specialist literature and fiction. In that way the students create a social room, where voices from the student's group are mixed with voices from other texts, and in this room a network of intertextual relations emerges. Hence the student voices become polyphony reports where we can hear many voices from different texts and times.

So the students' discursive actions are related to different contexts, but what is a context and what contexts are relevant? The concept of 'context' seems hard to define. Linell (1998) has proposed the following view:

Nothing is a context of a piece of discourse in and by itself, as it were "objectively". Instead, we have contextual resources, potential contexts that can be made in to actual, relevant contexts through the activities of the interlocutors in dialogue (Linell, 1998, p. 128). 
This way the students' talk in interaction is "embedded within, or activates, a matrix of different kinds of contexts (or dimensions of context)" (Linell, 1998, p. 128). From this point of view the contexts also become more or less a social construct, or, as Linell (1998) puts it: "relevant contexts are constructed for, in and through communicative projects. Contexts are themselves, to some extent, communicative constructs" (p. 138).

Linell (1998) uses concepts like 'context space', 15 'dimensions of context' and 'contextual resources' almost interchangeably, but here they will be used with a different emphasis. As mentioned, no utterance is constructed within a social vacuum and isolated from its context. Instead, language is created within a contextual space, where the total contextual resources are the potentially available means in different contextual dimensions. During interaction, different parts of the contextual resources in time and space are triggered and become activated.

So when the students are using different types of quotations and allusions in group discussion, they are in a constant interplay with their contextual resources. Roughly we can discriminate between references within or outside the immediate context. If the speaker is referring to an utterance from within the very same text or discourse (here and now) we can talk about an intratextual relation, as in the following example:

\section{(4) $[\mathrm{GG} 5: 105]$}

Yvette: -You can do a lot through playing. Like Hanna mentioned that children learn these kinds of nursery rhymes early and, which you see can be developed into a lot more as well. [-Man kan göra mycket genom lek. Som Hanna nämnde att barn lär sig tidigt såna här ramsor och, som man ser kan utvecklas till mycket mer också.]

Here Yvette is referring to a present speaker, Hanna, trying to connect her examples to the concept of learning "through playing" and pointing out the importance of playing in a developmental perspective. This is not, however, an immediate verbal response to Hanna. Instead, this is an example of a reference to what was said earlier in the same conversation (cf. Bentley, 1997). Some references in the study emerge several turns later or when the topic has been changed, but in this case Yvette is picking up a statement by Hanna some twenty minutes later. This kind of reference, within the same text and concrete situation, I will place in the contextual dimension of the situation.

If, on the other hand, the speaker is referring to an utterance from another text or discourse (then and there) we can talk about an intertextual relation (Fairclough, 1996). In the previous examples 1- 3, the students are referring to encounters before and outside the present situation. Lectures (1), Specialist Literature (2) and Practice (3) are all important parts of their teacher training, referring to an utterance from another text or discourse. I will place this kind of 
reference, relating to a part of the teacher training, in the contextual dimension of education.

There is however a third contextual dimension that I will call the culture and society context, because the reference concerns neither the situational setting, nor the educational setting. Generally speaking, it includes different kinds of specific socio-cultural background knowledge, assumptions or experiences. In the next example Margaretha is quoting one of her former teachers and hence using her background knowledge in supporting the statement that children are indeed "very different":

\section{(5) [GG5:154]}

Margaretha: -I had a teacher once who said this: "To put children at the same age in the same class is like classifying according to the size of shoes." And that is really a pretty wise thing to say, because they are very different. [-Jag hade en lärare en gång som sa det: "Å sätta barn som är lika gamla i samma klass det är som att sortera efter skostorlek.” Och det är faktiskt rätt så klokt sagt, för dom är väldigt olika.]

Now we can distinguish between three different contextual dimensions, namely the situational, the educational, and the cultural and society dimension. ${ }^{16}$ The students, then, creating a social room of relations, refer to intratextual relations concerning the situational dimension, and to intertextual relations concerning the educational and the cultural and society dimension.

As mentioned earlier, there is a constant interplay with the contextual resources. Before we continue, I will mention some of the complexity behind the concept. In the following example, Siv activates three contextual resources within the same utterance when she refers to books and practice, in the education dimension, and her own school experience in the culture and society dimension:

\section{(6) $[\mathrm{GG} 4: 51]$}

Siv: -I think that's a pity, that, that you don't see it in reality, I mean you read about it in the books, but, when you come out, you haven't $[\mathrm{xx}]$ it yourself on your, when you went to school, and when you come out on practice you don't see it, because it's still the traditional, so you only see what you already know from experience. [-Det tycker jag är synd, att, att man inte ser det i verkligheten, alltså man läser om det i böckerna, men, när man kommer ut, man har inte [ohörbart] det själv på sin, när man gick i skolan, och när man kommer ut på praktikplatser så ser man inte det, för det är ändå det traditionella, så det är ju det man kan redan som man ser.]

Siv is complaining about the traditional school education through comparing her own background, when she went to compulsory school with what she has read in the literature and seen on her teaching practice during the course. In doing so she is activating the contextual resources labeled Specialist 
Literature, Practice, and School Tradition and Experience. But only small pieces of the contextual resources in the clusters are actually activated and made relevant during the students' interaction.

In the previous examples we have seen Hanna (2), Yvette (3) and Margaretha (5) activate the same contextual resource, but a different part of the cluster. Thus, Hanna is referring to a specific book in mathematics while Siv alludes to a group of books on educational theory. Yvette is pointing out her personal thoughts while Siv is aiming at a common experience after the teaching practice, and Margaretha, finally, is talking about a teacher from her own school experience while Siv is referring to the school tradition in Swedish society.

So, when it comes to references to books, for instance, the students are not necessarily referring to the same book, and even if they are, it is not necessarily the same part of the book, and if they really hint at the same part of the book they might have different quotes or interpretations. Consequently, we not only have potential and activated contextual resources, but also multiple contexts and multiple interpretations in the same cluster, used as contextual resources in the same educational setting.

Nevertheless, the contextual resources have been combined in clusters ad hoc during the analysis with the focus on the source in time and space. The borders between the clusters are not definite. Instead the clusters vary and overlap considerably. The students' school experiences, for instance, are divided into four clusters (in two dimensions): School Tradition and Experience, when it comes to their own schooling; Work Experience, if they have been working as a substitute; Practice, concerning practical knowledge of education during the course, and Earlier Courses, if they are referring to the practice during the first year of teacher training.

Two other examples of fluent borders are Notes and Other. Notes are problematic because they have probably been done during reading, lessons, lectures or discussions, and Other because sometimes the reference is not specific enough in time and place for the observer to determine exactly what part of the education dimension the student is referring to. When the reference is to a text book, for example, the context is usually not obvious. Finally, we have a similar kind of problem in Group Discussion and Earlier Group Guidance, where the students occasionally refer to these clusters even though it is obvious to the observer that the cluster in question is not the primary source, but rather the latest occasion when the subject was discussed.

So, the clusters are a simplification of a complex matter, where the students bring along many small and different pieces of contextual resources into the situation dimension. But here our primary objective is to examine what kind of sources the students are referring to during interaction. 


\section{METHODOLOGY}

Participants and course

In this qualitative study, eight white Swedish middle-class students in the middle of their teacher training were involved in problem-based learning with a tutor for half a year. The group, one man and seven women, was not put together for the purpose of this study, but as a working unit during the course. ${ }^{17}$ The course comprised two periods of practical knowledge of education and integrated some subject areas, including language and literature, mathematics, educational theory and methodology.

During the course the student group interacted seven times with the tutor (group guidance) and with an observer present. ${ }^{18}$ The observer was not previously known to the student group, but was a former member of the teacher team and had been teaching a course of the same kind to other students the year before. This meant that the lessons and literature as well as lectures and other parts of the course were well known to the observer. So the observer played the role of a well-informed and at time times very well-informed, teacher.

\section{Materials}

The seven group guidance sessions with the tutor were videotaped, so the data material includes seven video texts, one video text for each group guidance, with a total of 12 hours. Every group guidance lasted for 90 minutes except group guidance number five, which was an oral group examination and lasted for three hours.

The group met with their tutor in an ordinary classroom, with the video recording in one corner all the time and the observer writing field notes in the opposite corner. The students and their tutor sat in the middle of the room with four microphones on the desks in front of them, one microphone on each desk and between two students, and with the desks forming a big V, so that the participants could see each other and everybody was visible in profile in the camera.

\section{Data analysis}

Intertextuality, as an aspect of Bakhtin's dialogism, is a possible perspective on all oral and written texts, but as a methodological concept it is to abstract and general and therefore not applicable. With Fairclough's (1996) distinctions though, it is possible to make text analyses with manifest and sequential intertextuality. The time perspective also makes Bentley's (1997) distinctions between different kinds of post-listening useful, and among the links in the chain of speech communication in the past the study focuses on long-term 
listening. Following Bakhtin (1999 [1986]) the utterance is the fundamental unit of analysis, and adopting Linell's (1998) view on contextual resources the examples can be combined ad hoc into clusters during the analysis, categorized and divided into different contextual dimensions (Hellspong \& Ledin, 1997).

In this study the students are listening to voices from the past, postlistening, and giving a long-term verbal response in the form of a reference in the present conversation. The students' dialogical response, the students' voice response, creates different patterns of reported listening, and the patterns display the repertory of contextual resources in use. The object of inquiry is more or less explicit references, thus the voices from the contextual resources in use are signaled in the students' utterances (Thompson, 1996). So the criterion of the example selection is that the students are explicitly referring to sources in the past, such as a person $(1,4 \& 5)$, a thing $(2 \& 6)$, a place ( $3 \& 6)$ or an event (6). How explicit the students are however varies over time. What needs to be explicitly said in the beginning of the course is later on a part of the common context and so the students in the group just need a hint to know what lecture or book somebody is reporting from. But this also means that a reference that is obvious for one group member could be difficult for another or the teacher, impossible for an observer and invisible for a reader.

On the one hand the number of potential contextual resources is openended, but on the other hand the students themselves reduce the list by demonstrating which resources are momentarily relevant to them in the ongoing interaction (Nofsinger, 1997). The concept of intertextuality, the boundaries of the utterance and the notion of long-term listening provide a data-based rationale for selecting certain contextual resources for study.

\section{RESULTS}

Group using contextual resources

In the students' dialogue, a room of intratextual and intertextual relations emerges, where many voices from many times and places are heard and used in a social construct. The discourse in the seven video texts is embedded within a contextual space, which includes the total contextual resources of the group. All the references to different voices and experiences can be combined in clusters of contextual resources that, following Linell (1998), are actually activated and made relevant during interaction. The clusters, finally, can be divided into the three earlier mentioned contextual dimensions of the situational, educational and society settings. The interplay with the activated contextual resources during interaction can be visualized as in Figure $1 .{ }^{19}$

In the middle of the diagram within the contextual dimension of situation, there are 36 examples of intratextual references, where the eight students are 
using each other's earlier statements in the present situation as (eight clusters of) contextual resources. This is shown in the previous example (4), when Yvette is referring to what Hanna (Ha) said earlier in the same conversation about learning through playing (the examples 1-6 of contextual resources mentioned earlier are marked light Grey in the figure). 
Figure 1

Examples distributed in clusters of activated contextual resources in three dimensions during interaction in videotext I-VII

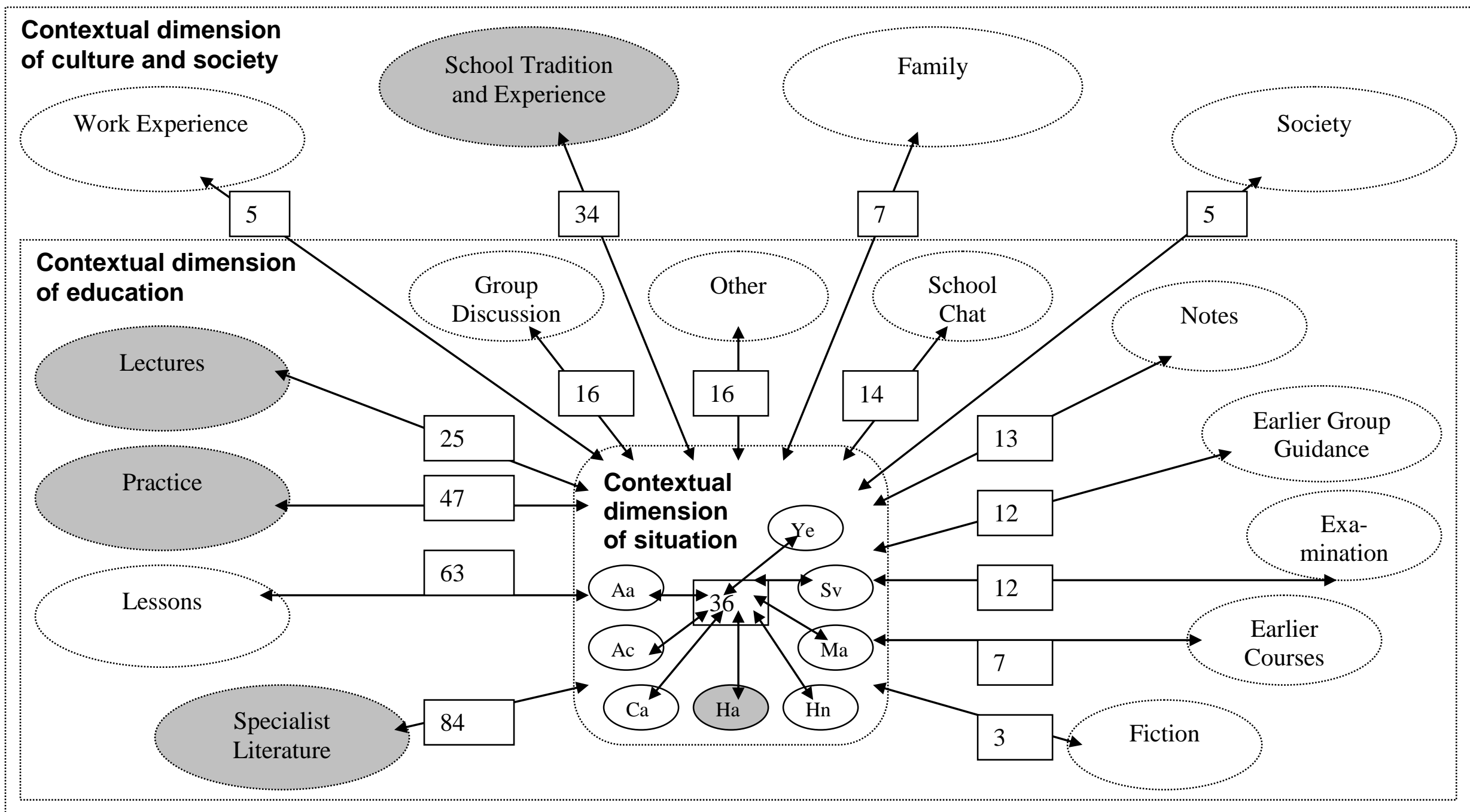


Mostly though, the students are making intertextual references to other texts and discourses outside the present situation, namely to clusters of contextual resources in the contextual dimensions of either education or society. The contextual dimension of education contains twelve clusters of contextual resources, with the highest rates to the left (Specialist Literature) and the lowest to the right (Fiction). The previous examples of reference to Lectures (1), Specialist Literature (2) and Practice (3) are all contextual resources that are brought into the present situation from the education dimension.

Finally, Margaretha (5) gives an example from the contextual dimension of culture and society, when she uses her school experience and quotes one of her former teachers. This is one of four clusters in that dimension, with slightly more examples than the situation dimension but not as many as the dominating education dimension.

It is important, though, to emphasize that the diagram is supposed to be a picture of a contextual space with some contextual resources in three possible contextual dimensions. The figure does not show all the potential contextual resources of the group, nor does it show what part of the contextual resource is activated. In the diagram we can only see what cluster the activated contextual resource belongs to or has been categorized as. In the contextual space there are no closed rooms and the arrows, pointing in both directions, suggest the dynamics during the interplay.

As shown in Figure 1 we have a contextual space with 24 clusters of activated contextual resources during interaction in videotext I-VII. The clusters are divided into the three contextual dimensions, with eight in the situation dimension, twelve in education and four in the society dimension. In the selection for this article, however, I will focus on the dominating contextual dimension of education, comprising $78 \%$ of the examples of reported listening.

In the contextual dimension of education, then, we can notice the big difference in numbers between Specialist Literature (84) and Fiction (3). We can also notice that the connection with previous parts of the education, like Earlier Courses (7), seems to be weak when it comes to explicit references. Another interesting fact is that Group Discussion (16) and Earlier Group Guidance (12) together have slightly more examples of voice response than Lectures (25). Finally we can observe that the five major clusters, that is Specialist Literature, Lessons, Practice, Lectures and Group Discussion, have $75 \%$ of the total number of references, with Specialist Literature as the students' main source of references.

When we have established what contextual resources the students are activating in dialogue, we want to know how they are distributed across students, both each cluster on eight students and each student on twelve clusters. Table 1 and 2 represent this information. I will start with some general comments on Table 1, followed by looking at the clusters distributed on 

Table 1

Clusters of contextual resources distributed as percentages on students in the contextual dimension of education

\begin{tabular}{|c|c|c|c|c|c|c|c|c|c|c|c|c|c|}
\hline & \begin{tabular}{|l} 
Spe- \\
cialist \\
Litera- \\
ture \\
$(\mathrm{N}=84)$
\end{tabular} & $\begin{array}{l}\text { Lessons } \\
(\mathrm{N}=63)\end{array}$ & $\begin{array}{l}\text { Practice } \\
(\mathrm{N}=47)\end{array}$ & Lectures & $\begin{array}{l}\text { Group } \\
\text { Discus- } \\
\text { sion } \\
(\mathrm{N}=16)\end{array}$ & $\begin{array}{l}\text { Other } \\
(\mathrm{N}=16)\end{array}$ & $\begin{array}{l}\text { School } \\
\text { Chat } \\
(\mathrm{N}=14)\end{array}$ & $\begin{array}{l}\text { Notes } \\
(\mathrm{N}=13)\end{array}$ & $\begin{array}{l}\text { Earlier } \\
\text { Group } \\
\text { Guid- } \\
\text { ance } \\
(\mathrm{N}=12)\end{array}$ & $\begin{array}{l}\begin{array}{l}\text { Exa- } \\
\text { mination }\end{array} \\
(\mathrm{N}=12)\end{array}$ & $\begin{array}{l}\text { Earlier } \\
\text { Courses } \\
(\mathrm{N}=7)\end{array}$ & Fiction & $\begin{array}{l}\text { Total } \\
(\mathrm{N}=312)\end{array}$ \\
\hline Annika & $17 \%$ & $16 \%$ & $19 \%$ & $20 \%$ & $19 \%$ & $0 \%$ & $36 \%$ & $31 \%$ & $25 \%$ & $8 \%$ & $29 \%$ & $0 \%$ & $18 \%$ \\
\hline Yvette & $13 \%$ & $11 \%$ & $15 \%$ & $8 \%$ & $38 \%$ & $56 \%$ & $43 \%$ & $8 \%$ & $17 \%$ & $33 \%$ & $14 \%$ & $0 \%$ & $18 \%$ \\
\hline Siv & $11 \%$ & $24 \%$ & $23 \%$ & $24 \%$ & $6 \%$ & $19 \%$ & $7 \%$ & $0 \%$ & $8 \%$ & $17 \%$ & $14 \%$ & $0 \%$ & $16 \%$ \\
\hline $\begin{array}{l}\text { Ann- } \\
\text { Christin }\end{array}$ & $18 \%$ & $19 \%$ & $6 \%$ & $32 \%$ & $0 \%$ & $6 \%$ & $7 \%$ & $15 \%$ & $25 \%$ & $17 \%$ & $0 \%$ & $33 \%$ & $15 \%$ \\
\hline Hanna & $11 \%$ & $8 \%$ & $9 \%$ & $4 \%$ & $13 \%$ & $6 \%$ & $0 \%$ & $23 \%$ & $17 \%$ & $25 \%$ & $0 \%$ & $33 \%$ & $10 \%$ \\
\hline Cecilia & $12 \%$ & $11 \%$ & $11 \%$ & $4 \%$ & $19 \%$ & $0 \%$ & $0 \%$ & $15 \%$ & $0 \%$ & $0 \%$ & $14 \%$ & $0 \%$ & $9 \%$ \\
\hline $\begin{array}{l}\text { Marga- } \\
\text { retha }\end{array}$ & $12 \%$ & $8 \%$ & $6 \%$ & $8 \%$ & $6 \%$ & $6 \%$ & $7 \%$ & $8 \%$ & $8 \%$ & $0 \%$ & $29 \%$ & $33 \%$ & $9 \%$ \\
\hline Håkan & $7 \%$ & $3 \%$ & $11 \%$ & $0 \%$ & $0 \%$ & $6 \%$ & $0 \%$ & $0 \%$ & $0 \%$ & $0 \%$ & $0 \%$ & $0 \%$ & $4 \%$ \\
\hline Total & $100 \%$ & $100 \%$ & $100 \%$ & $100 \%$ & $100 \%$ & $100 \%$ & $100 \%$ & $100 \%$ & $100 \%$ & $100 \%$ & $100 \%$ & $100 \%$ & $100 \%$ \\
\hline
\end{tabular}


students. In the next paragraph I will comment on Table 2 with the students distributed on the contextual resources and finish by comparing Table 1 with Table 2.

If we begin with the figures in the last column to the right in Table 1, showing the total of examples distributed on students, we can easily categorize the students in three levels according to their total percentages of reported listening. If the examples of voice response were distributed evenly in the group, each student would have 12-13\%. Instead, we have a high level with 15-20\% of the examples (Annika, Yvette, Siv \& Ann-Christin), a middle level with around $10 \%$ of the examples (Hanna, Cecilia \& Margaretha), and a low level with around $5 \%$ of the examples (Håkan).

If we look at the clusters and the numbers of students represented in each cluster, we get the following picture: the three major clusters, that is Specialist Literature, Lessons and Practice, have examples distributed on all the students, while eight clusters are missing between one and three students, and one cluster, Fiction, is distributed on less than half the student group, namely three students.

So, most of the students have examples from most of the clusters, but none has examples from all of them. Yvette, for instance, is missing just one cluster, while Håkan is only represented in four out of twelve clusters. A simple answer to that could be that Håkan was categorized as low level and Yvette as high level, according to their total percentages, and the higher the numbers the more clusters. But Margaretha, who was categorized as middle level, is represented in the same number of clusters as Yvette, and Hanna, also middle level, has the same representation as Annika, Siv and Ann-Christin on the high level. Thus, this is not only a question of the number of references, but also to what extent the numbers are distributed over different clusters.

The first column, with Specialist Literature, displays a fairly even distribution. Annika and Ann-Christin have high rates and Håkan a low one, but most of the students have percentages around the average. In fact, Specialist Literature is not only the dominating cluster within the education dimension, according to percentages, but also the most evenly distributed cluster in the student group (7-18\%).

In the second column we get a different picture. When it comes to Lessons, Annika, Siv and Ann-Christin have high rates, but the rest around average or lower with Håkan at the bottom. Among the top rates Siv dominates, with almost one quarter of the examples of reported listening referring to Lessons $(24 \%)$.

If we turn to Practice, in the next column, the picture is similar, with a top three and the rest average or lower. But now Yvette joins Annika and Siv at the top, while Ann-Christin and Margaretha have the lowest rates. Again Siv is close to having one quarter of the examples (23\%). We can also notice that here Håkan has his highest rate as a percentage in the group, reaching the average. 
In Lectures, we have the same top three as in Lessons, but the differences are greater. One student (Håkan) did not refer to Lectures at all, while Annika, Siv and Ann-Christin together have around $75 \%$ of the references to Lectures. Here we can also notice that Ann-Christin dominates, with close to one third of the examples on reported listening (32\%).

When we look at the rest of the clusters, we have to remember that low numbers can give high percentages. But with that in mind we can conclude: Yvette dominates in both Group Discussion and Other (even though Cecilia has her highest rate in the group in the former), while in School Chat Yvette dominates together with Annika. In Notes, Earlier Group Guidance, Examination and Earlier Courses, the few examples are distributed quite evenly among the students represented, and in Fiction, finally, three students have one single example each.

To sum up, we have some interesting facts about the clusters distributed on the student group. First, there seem to be only a few students dominating some of the clusters, such as Annika and Ann-Christin in Specialist Literature, Siv and Ann-Christin in Lessons, and Annika and Siv in Practice, and sometimes quite strongly, like Ann-Christin in Lectures (32\%) and Yvette in Group Discussion $(38 \%)$ or Other $(56 \%)$. This means, for instance, that when the group uses their contextual resources from the cluster of Lectures in their creation of meaning, almost one third of the voice response comes from Ann-Christin.

Secondly, those on the high level, according to the total percentages, are not always on top in the different clusters, such as Ann-Christin in Practice (6\%) and Yvette in Lectures (8\%). Thirdly, the differences between high and low rates for each student can be considerable, like the figures for Ann-Christin (6$32 \%)$ or Håkan $(0-11 \%)$. These facts are reflected in the individual results concerning how each student is distributed on clusters in the education dimension.

\section{Students' listening repertory}

The previous section presents how the clusters are distributed in the group and gives a picture of how the group uses their total contextual resources. Now we change perspective, looking for the student's individual repertory concerning the explicit reported listening. This means that we are interested in the different patterns created by the individual voice response.

If we look at Annika, on the first line she has three clusters of contextual resources with an above average percentage, namely the three major clusters of Specialist Literature, Lessons and Practice. This means that when she uses her contextual resources, almost $60 \%$ of her voice responses come from those three clusters. But she also has two clusters close to the average and five minor clusters, covering ten out of twelve clusters. Looking at it this way, she has a 
Table 2

Students distributed as percentages on clusters of contextual resources in the contextual dimension of education

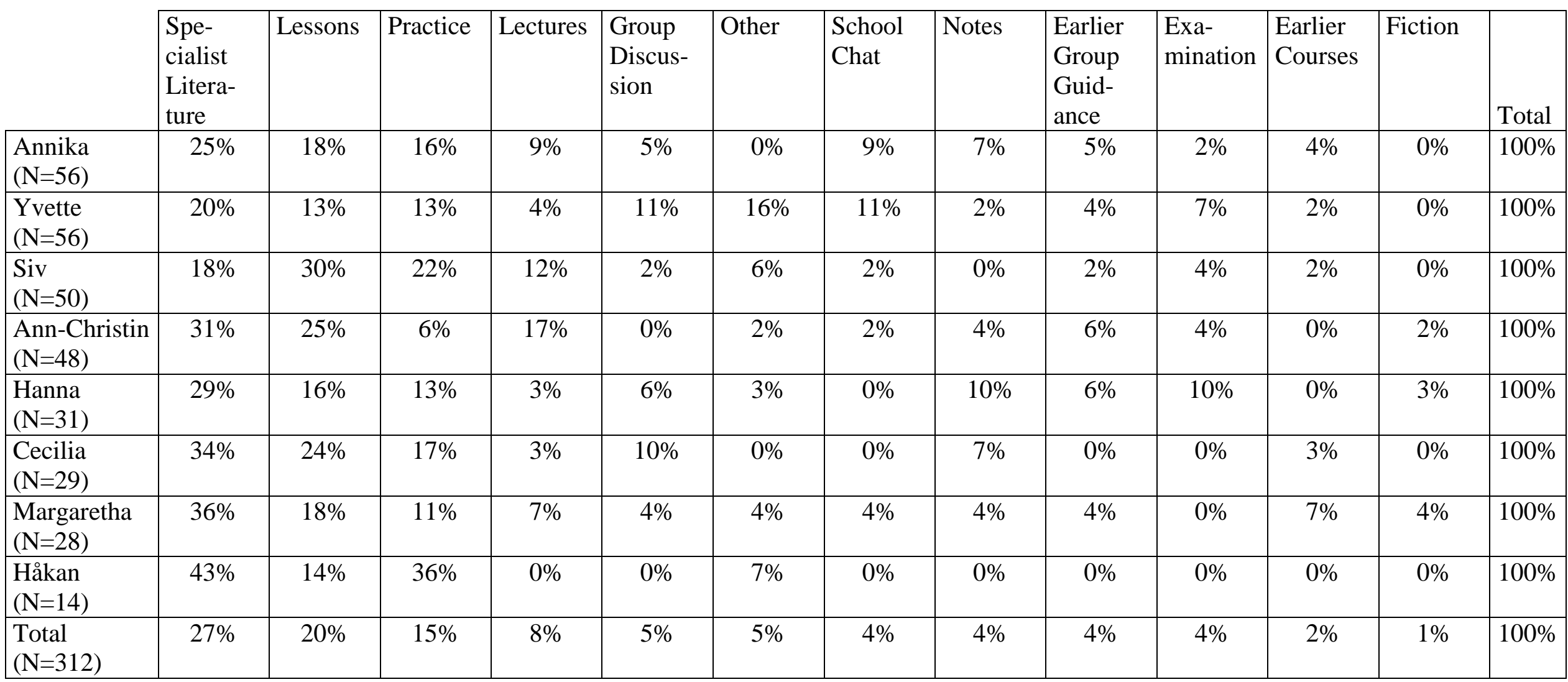


broad and quite even repertory of reported listening.

Yvette, on the next line, presents a different picture. She covers eleven out of twelve clusters in the education dimension. We can notice that she has only two clusters with a percentage over the average, but four around the average and five minor clusters. She also has a low rate on Lectures. Her dominating clusters are Specialist Literature and Other, which include more than one third of her references. In fact she has the highest rates in the group on Other (which means that she is not too specific about what context she is referring to in those examples). Yvette too has a broad listening repertory, but she also has the most even repertory in the group.

If we turn to Siv, we notice that she also has a broad repertory, covering ten clusters and only missing Notes and Fiction. But she has three major clusters, one around the average, and six minor clusters. Her dominating clusters are Specialist Literature, Lessons and Practice, comprising 70\% of her examples of reported listening. Siv's repertory is almost as broad as Yvette's, but not as even. In the group she has the highest rates on Lessons, according to percentage (30\%), and Practice, according to numbers (11).

Ann-Christin is the last of the four students on the high level according to their total percentage on reported listening (see Table 1). Her three very dominating clusters are Specialist Literature, Lessons and Lectures, with nearly three quarters of her examples, but she has a low rate on Practice. She also uses contextual resources from ten clusters, but the remaining seven clusters are all minor, so she has a broad but more uneven repertory of voice response.

In comparison with the preceding four, who all are on the high level, Hanna is on the middle level. This is important to have in mind, because otherwise the percentage figures are misleading when it comes to small numbers. This means that Hanna has a lower number of references distributed over the clusters. Hanna, then, also has a broad repertory, covering ten clusters, even though she is on the middle level. Like Annika, almost 60\% of her voice responses comes from Specialist Literature, Lessons and Practice, that is, Hanna shows a similar pattern on a lower level.

Looking at Cecilia's repertory, we find that she is missing five clusters and has three dominating clusters, Specialist Literature, Lessons and Practice, covering more than three quarters of her references. Her repertory is more narrow than the preceding students' and more uneven.

Margaretha, the last of the three students on the middle level, has a lower number of references but covers as many clusters as Yvette on the high level, that is eleven out of twelve. Almost two thirds of her examples come from the three major clusters, Specialist Literature, Lessons and Practice. Her repertory is as broad as Yvette's but not as even.

Håkan, finally, is the only group member on the low level according to total percentages. His repertory shows only four clusters, which means that he never refers explicitly to eight of the clusters. The dominating clusters in his 
references, Specialist Literature and Practice, comprise almost $80 \%$ of the examples. We can conclude that he has a narrow listening repertory of reported listening, and he also has the most uneven repertory in the group.

Now, if we compare how the group uses their contextual resources (Table 1) with the students' individual repertories (Table 2), we find one of three possibilities: the students use their contextual resources more in the group, less in the group, or as much in the group as in their individual repertory.

In the first case we notice that Ann-Christin, for instance, uses $17 \%$ of Lectures in her individual repertory (Table 2). But in the group her references to Lectures represent $32 \%$ of the total contextual resources in that cluster (Table 1). The same goes for Annika (9\% respectively 20\%) and Siv (12\% respectively $24 \%$ ) in that cluster. So Annika, Siv and Ann-Christin seem to be important group members when the group is using the cluster of Lectures in their social construct.

On the other hand, Specialist Literature (34\%) and Practice (36\%) seem to be important clusters in Cecilia's and Håkan's individual repertory (Table 2). But in the interaction with the group they contribute around the average, $12 \%$ and $11 \%$ respectively (Table 1 ). In some cases, though, the difference between the individual use and the group use of contextual resources can be considerable. Håkan, for example, has the dominating cluster of Specialist Literature (43\%) in his repertory (Table 2), while his contribution is below average (7\%) in the group (Table 1).

A third possibility is that there is no major difference between the individual repertory and the group's use of the contextual resources. In Yvette's individual repertory, she uses $13 \%$ of her contextual resources from the cluster of Lessons (Table 2) and in the group her contribution is 11\% (Table 1). For Siv, in the cluster of Practice, the figures are 22\% (Table 2) and 23\% (Table 1) respectively. So while Yvette contributes around the average and Siv above average, their use of contextual resources in the clusters mentioned seems to mean as much to the individual repertory as to the group.

The results from the students examined suggest that there is a continuum in their long-term listening repertory, from a broad and even repertory to a narrow and uneven repertory of reported listening in educational settings. Furthermore we can conclude that the differences between the individual use and the group use of contextual resources seem to make some of the students important contributors in certain clusters of contextual resources in the group during interaction.

\section{CONCLUSION}

When the students construct their knowledge in educational settings, they do not ask whether the source of information is spoken, written or shown. 
Instead they give and take from what they have heard, read and seen within their experiences. The purpose of this study was to describe the students listening to voices through the concept of intertextuality and within a theoretical framework across disciplinary boundaries. Analyses of the data obtained from students in the middle of their teacher training revealed that students have different patterns of explicit reported listening, and thus different listening repertories of contextual resources.

In discussing the intellectual structure of listening studies, Wolvin et al. (1999) make a distinction between the following five complementary domains of scholarly inquiry: listening research, listening theory, listening assessment, listening instruction, and listening practice. Starting with listening research, the implications from this study are the presentation and suggestion of $a$ new and alternative methodology in the field of listening research, with listening as a social and intertextual phenomenon within the frameworks of Bakhtin (1984 [1929/1963], 1999 [1986], 2000 [1979]).

Purdy (1988) has outlined some parallels between reader/reception theory and listening as "the receptive dimension of interpersonal communication" (p. 1). This article is another step in that direction of expanding our understanding of the receptive process and responsive understanding of communication. The applied method of analysis points towards the need for a listener reception theory, and thus addresses the domain of listening theory.

This qualitative and descriptive research was not primarily written to investigate alternative forms of listening assessment, but to some extent it could be used as such. By tracing intertextual listening across an array of social, cultural and personal relationships in the discursive field of education, it is possible to follow the involvement of the individual listener in the field as well as the creation of that field by the group. This way the students' repertories in educational settings provide a rough measure of the qualitative sense of listening in describing the social interaction that has taken place.

When it comes to listening instruction, the most important implications of the study are to offer a new tool for an awareness of the individual and joint participation in the discursive creation by both teachers and students. This awareness of voice response and different listening repertory brings into focus the importance of response, the attention to the interplay between different contextual resources in different contextual dimensions, and the key pedagogical question under what conditions these contextual resources become activated when we construct our knowledge.

In everyday listening practice in the classroom, finally, there are several reasons for the teacher to observe the students' reported listening when they are interacting in small groups. First, by listening to the students' voice response the teacher gets an overall picture of the listener's long-term reception in real-time listening contexts. The reported listening does not display all the voices the students have encountered, but only the voices they explicitly activate in the 
situational setting. So not having an elaborated intertextual behavior means only that references are not made explicitly.

Second, the students' repertories demonstrate what contextual resources the individual student finds it relevant to make explicit in the social construct. This gives the teacher an entrance to the student's experiences and a point of departure in the pedagogical planning and development of teaching. Third, the individual pattern of reported listening becomes an analytical tool for making the teachers and the students aware of their developmental possibilities in listening. This way the feedback to the students makes their intertextual and contextual relations in time and space available for reflection and evaluation, using key pedagogical concepts like dialogue, voice and response. The dialogical perspective may be summed up as the students' confrontation with and use of other voices in making a voice of their own in teacher training.

It is impossible, of course, within the limits of an article to do any justice to the discursive field of education with six text examples of voice response. A theory of language that emphasizes process rather than system should however analyze some longer sequences of talk in interaction that clearly show the contribution of explicit reported listening to talk in interaction.

Another problem of the study is that different types of representation of explicit reported listening are merely indicated but not as yet developed. By combining and comparing the results of the group using contextual resources, like high and low level (Table 1), with students' listening repertories, like broad/narrow and even/uneven (Table 2), this should however be possible.

In this paper I have looked at long-term listening as an intertextual activity and used signaled voices in present conversation as an indication of different listening repertories in a student group. The results presented are a preliminary analysis for my dissertation,,$^{20}$ and in the selection for this article I have focused on the clusters of contextual resources in the dominating dimension of education. The results suggest that some of the students have a broad and some a narrow listening repertory of contextual resources, and that during interaction some of the students seem to be more important contributors in certain clusters than others in the group. Thus, the results say something about who is making references and to what extent (Table $1 \& 2$ ), what contextual resource they are using and to what extent (Figure 1), but nothing about why they are referring as they do. In the forthcoming analysis I will examine the function of these utterances, that is, how the students use these voices during the process and thus, how their reported listening contributes to the interaction. 


\section{NOTES}

Authors' note: A version of this manuscript was presented at the $22^{\text {nd }}$ annual convention of the International Listening Association (ILA) in Chicago, Illinois, USA, March 24, 2001, where the paper received an award for nonstudent research in the field of listening. The author is grateful for feedback from the respondent Michael Purdy in Chicago, the editorial board reviewers and the tutor Caroline Liberg in Malmoe, Sweden. Correspondence concerning this article should be sent to Kent Adelmann, School of Education, Malmoe University, SE-205 06 Malmoe, Sweden. E-mail: Kent.Adelmann@lut.mah.se

${ }^{1}$ Julia Kristeva (1967), Bakhtine, le mot, le dialogue et le roman, in Critique 23, p. 440.

${ }^{2}$ For an introduction to Bakhtin, see: Clark \& Holquist (1984), Mikhail Bakhtin.

3 The $1^{\text {st }}$ edition of the Dostoevsky book appeared in 1929 under the title Problems of Dostoevsky's Art, and the expanded $2^{\text {nd }}$ edition, Problems of Dostoevsky's Poetics, was published in 1963. In preparation for the revision Bakhtin made some notes in 1961 which were published in 1977 and are included in Appendix II in the volume of 1984. Bakhtin's definition of voice belongs to those notes and shows a remarkable continuity in his way of thinking.

${ }^{4}$ In the editor's preface to Bakhtin (1984) Caryl Emerson states that Bakhtin has a "fondness for military metaphors" (p. xxxvii).

5 Baxter \& Montgomery (1996) capture these four kinds of linkages in the chain of an utterance visually in a figure on p. 29.

${ }^{6}$ For an introduction to dialogism, see: Michael Holquist (1990), Dialogism: Bakhtin and his world.

${ }^{7}$ See also Cornwell \& Orbe (1999) for an emphasis on listening in dialogic relationships.

${ }^{8}$ The author is grateful for comments from Michael Holquist during the Bakhtin Day at Stockholm university, Sweden, September 27, 2001, concerning Bakhtin's relationship to listening.

${ }^{9}$ In Volosinov (1996), Appendix II, p. 176, note 3, Titunik claims that brief mentions of the existence of the Bakhtin Circle appeared in two books on psycholinguistics in 1967 and 1968. Besides Bakhtin the "group" consisted of among others Valentin Nikolaevich Volosinov (1895-1936), Matvei Isaevich Kagan (1889-1937), Pavel Nikolaevich Medvedev (1891-1938), Lev Vasilievich Pumpianskii (1891-1940) and Ivan Ivanovich Sollertinskii (1902-1944) (Brandist 1997).

${ }^{10}$ Marxism and the Philosophy of Language was published with a $1^{\text {st }}$ edition in 1929 and a $2^{\text {nd }}$ edition in 1930. The first complete English translation, including Appendix by the translators Ladislav Matejka and I.R. Titunik, appeared in 1973 following the $2^{\text {nd }}$ edition.

${ }^{11}$ Volosinov (1996), Appendix II by Titunik, p. 191, note 18: "The Russian term cuzaja rec' means both 'reported speech' in the technical sense and, literally, 'another's', or 'other', or 'alien speech'. Thus, the Russian term itself includes the double frame of reference so vital to Volosinov and Baxtin's [Bakhtin's] theories. That double reference could not be reproduced in English with any single term and had to be shared out between 'reported speech' and 'another's speech'."

${ }^{12}$ Goodwin \& Duranti (1992) provide a historical review of the concept.

13 Owen (1997) makes a brief presentation of Pepper's root metaphor theory in World hypotheses (1942) and summarizes the four "relatively adequate" world views: formism, mechanism, organicism, and contextualism.

${ }^{14}$ All the students in this study are Swedes and their names have been substituted with other Swedish names. 
15 Linell (1998) takes the concept 'context spaces' from Rachel Reichman (1978), Conversational coherency, in Cognitive Science 3, 283-327.

16 This triplet of contexts was formulated, slightly differently, by Hellspong \& Ledin (1997), who are referring to the works of M.A.K. Halliday. According to Linell (1998) "triplet tends to reappear quite often in the literature" and on page 133 in note 13 he mentions some other ways to categorize dimensions of contexts.

${ }^{17}$ Perspectives like gender or social and cultural differences are not taken into account in this study.

18 The present author.

${ }^{19}$ The figure has a certain container model ring. It seems to imply that the contexts are related to each other like 'Russian dolls', or to indicate a fixed hierarchy of contextual dimensions, but this is not the case. Unfortunately, it is easier to imagine the dynamics in words, using metaphors such as 'space' and 'dimension', than to show it in a static picture.

${ }^{20}$ Since this is a work in progress it should also be read as such. 


\section{REFERENCES}

Bakhtin, Mikhail. (1984 [1929/1963]). Problems of Dostoevsky's Poetics (2 ${ }^{\text {nd }}$ ed.). Theory and History of Literature, Volume 8 . Edited and translated by Caryl Emerson. Introduction by Wayne C. Booth. Manchester: Manchester University Press.

Bakhtin, Mikhail. (1999 [1986]). Speech Genres and Other Late Essays. Translated by Vern W. McGee. Edited by Caryl Emerson and Michael Holquist. Austin TX: University of Texas Press.

Bakhtin, Mikhail. (2000 [1979]). Författaren och hjälten $i$ den estetiska verksamheten. [Author and Hero.] Gråbo: Bokförlaget Anthropos.

Baxter, Leslie A. \& Montgomery, Barbara M. (1996). Relating: Dialogues and Dialectics. N.Y.: The Guilford Press.

Bentley, Sheila C. (1997). Benchmarking Listening Behaviors: Is Effective Listening What the Speaker Says It Is? In International Journal of Listening, 11, 51-68.

Brandist, Craig. (1997). The Bakhtin Circle. In The Internet Encyclopedia of Philosophy. Retrieved December 11, 1999, from http://www.utm.edu/research/iep/b/bakhtin.htm

Cornwell, Nancy C. \& Orbe, Mark P. (1999). Critical Perspectives on Hate Speech: The Centrality of "Dialogic Listening". In International Journal of Listening, 13, 75-96.

Dysthe, Olga (Ed.). (1999). The dialogical perspective and Bakhtin. Conference Report. Programme for Research on Learning and Instruction, PLF Rapport 2/99. Bergen: University of Bergen.

Fairclough, Norman. (1996 [1992]). Discourse and Social Change. Cambridge: Polity Press.

Glenn, Ethel C. (1989). A Content Analysis of Fifty Definitions of Listening. In Journal of the International Listening Association, 3, 21-31.

Goodwin, C., \& Duranti, A. (1992). Rethinking context: An introduction. In A. Duranti \& C. Goodwin (Eds.), Rethinking context: Language as an interactive phenomenon (pp. 1-42). Cambridge, England: Cambridge University Press.

Hellspong, Lennart \& Per Ledin. (1997). Vägar genom texten. Handbok $i$ brukstextanalys. [Ways through the text. Handbook in analyzing everyday prose.] Lund: Studentlitteratur.

Holquist, Michael. (1983). Answering as Authoring: Mikhail Bakhtin's TransLinguistics. In Critical Inquiry, 10, 2, 307-319.

Holquist, Michael. (1984). Mikhail Bakhtin. Cambridge, MA: Harvard University Press.

Holquist, Michael. (1990). Dialogism: Bakhtin and his world. London: Routledge. 
Linell, Per. (1998). Approaching Dialogue. Talk, interaction and contexts in dialogical perspectives. Amsterdam/Philadelphia: John Benjamins Publishing Company.

Mead, George H. (1976 [1934]). Medvetandet, jaget och samhället. Från socialbehavioristisk ståndpunkt. [Mind, Self and Society. From the standpoint of a social behaviorist.] Lund: Argos Förlag.

National Communication Association. (1998). Competent Communicators: K-12 Speaking, Listening, and Media Literacy. Standards and Competency Statements. Annandale, VA: National Communication Association.

Nofsinger, Robert E. (1997). Context and Conversational Processes. In James L. Owen (Ed.), Context and Communication Behavior (pp. 355-367). Reno, NV: Context Press.

Owen, James L. (1997). World Views as Context for Communication Studies. In James L. Owen (Ed.), Context and Communication Behavior (pp. 17-39). Reno, NV: Context Press.

Purdy, Michael. (1988). Reader/Reception Theory and Listening Theory. Paper presented to the New York State Speech Communication Association (NYSSCA), Ellenville, N.Y., October 1988.

Purdy, Michael. (1997). What is listening? In M. Purdy \& D. Borisoff (Eds.), Listening in Everyday Life. A Personal and Professional Approach $\left(2^{\text {nd }} \mathrm{ed}\right.$., pp. 1-20). Lanham, MD: University Press of America.

Thompson, Geoff. (1996). Voices in the Text: Discourse Perspectives on Language Reports. In Applied Linguistics, 17, 4, 501-30.

Volosinov, V.N. (1996 [1929/1930 \& 1973]). Marxism and the Philosophy of Language. Translated by Ladislav Matejka and I.R. Titunik. Cambridge, Mass.: Harvard University Press.

Vygotskij, L.S. (2000 [1934/1962]]. Thought and Language. Translation revised and edited by Alex Kozulin. Cambridge, MA: MIT Press.

Wertsch, James V. (1997 [1991]). Voices of the Mind. A Sociocultural Approach to Mediated Action. London: Harvester Wheatsheaf.

Wolvin, Andrew D., Halone, Kelby K. \& Coakley, Carolyn G. (1999). An Assessment of the "Intellectual Discussion" on Listening Theory and Research. In International Journal of Listening, 13, 111-129. 